\title{
ARCHEOLOGIA KLASYCZNA W POSZUKIWANIU SWEJ TOŻSAMOŚCI. MIĘDZY PRZESZŁOŚCIĄ, TERAŹNIEJSZĄ A HISTORIĄ SZTUKI*
}

\author{
CLASSICAL ARCHAEOLOGY IN PURSUIT OF ITS IDENTITY: \\ BETWEEN THE PAST, THE PRESENT AND THE HISTORY OF ART
}

\author{
Ewa Bugaj \\ Instytut Prahistorii, Uniwersytet im. Adama Mickiewicza \\ ul. Św. Marcin 78, 61-809 Poznań, Poland
}

\begin{abstract}
The article defines classical archaeology as one of the first and oldest branches of archaeology practised in Europe by stressing that interests in the relics of ancient civilisations have been deeply embedded in the cultural self-identification of various peoples of Europe. The author aims to recognize how the modern world values contribute to interpretation and conservation of the classical past, especially Greek art and architecture, alongside other ancient objects, and how the Western elites treated them in the past centuries. The issue of common roots of classical archaeology and history of art as well as their long-lasting relationships are also thoroughly discussed. Discrepancies between major research procedures of classical archaeology and art history are scrutinized, especially in terms of an arguable irrelevance of modern concept of art in relation to archaeological evidence. The role of museums in relation to art and antiquities trade is also raised. Furthermore, the author discusses classical archaeology within broader issues of contemporary archaeology. It is recognized that classical archaeology has certainly changed by resigning from the previously dominant connoisseur knowledge approach to artefacts, concentrated solely on the works of art often seen as autonomous entities devoid of the context of their production, meaning and perception. Finally, the author defines contemporary classical archaeology as a rapidly changing discipline, reformulating its research agenda and opening up to cooperation with numerous other disciplines. Nevertheless, this should not mean a wholesale rejection of its great legacy of being a history of ancient art. On the contrary, this traditions ought to be redefined and incorporated into contemporary research agenda of the discipline.
\end{abstract}

Archeologia klasyczna sytuuje się wśród tych odmian dyscypliny, które mogą wykazać się najdłuższą tradycją. Potwierdzić bowiem można już prawie dwustuletnią ciąg-

\footnotetext{
* Niniejszy artykuł jest znacząco przeformułowaną i rozszerzoną wersją tekstu okolicznościowego przygotowanego w języku angielskim („On the Past and Contemporary Character of Classical Archaeology”), który ukazał się drukiem w księdze jubileuszowej Profesora Leszka Mrozewicza (Studia Lesco Mrozewicz. Ab amicis et discipulis dedicata, ed. S. Ru ciński, C. Balbuza, Ch. Królczyk, Poznań 2011, s. 47-59).
} 
łość jej badań naukowych. Korzenie archeologii klasycznej upatrywane są jeszcze głębiej, a badacze wskazują najczęściej na czasy odrodzenia, charakteryzujące się wyjątkowym zafascynowaniem antykiem grecko-rzymskim, a szczególnie dziełami sztuki starożytnej ${ }^{1}$. Cofając się jeszcze bardziej, wykazać można, iż zainteresowanie pozostałościami cywilizacji starożytnych było wpisane bardzo głęboko w samodefiniowanie się rozmaitych ludów Europy, w podstawy ich tożsamości kulturowej, od czasów antycznych poczynając. $Z$ danych historycznych wiadomo, że starożytni Rzymianie wielce doceniali greckie dzieła sztuki, masowo je przywłaszczając i kopiując, a ów proces uznawania za swoją greckiej spuścizny kulturowej definiował i legitymizował ich własną kulturową dominację. Ponadto niektórzy z nich wypowiadali się o Grekach jako o ludziach, którzy uosabiają człowieczeństwo w najwyższym sensie, jak to wyraził w jednym z Listów Pliniusz Młodszy, zwąc Greków homines maxime homines ${ }^{2}$ i wyliczając związane $\mathrm{z}$ tym osiągnięcia ${ }^{3}$. Wyjątkową rolę następnie w utrwaleniu się znaczenia tradycji antycznych w Europie odegrało rozprzestrzeniające się chrześcijaństwo, a pozycja centralna eksponowania w tym procesie starożytności greckich, jak i rzymskich bierze się z faktu, iż chrześcijaństwo łacińskie i ortodoksyjne chrześcijaństwo wschodnie, tradycje te uznały za swoje i wplotły w swe dzieje ${ }^{4}$. Chrześcijaństwo po prostu bazowało na bogatym dorobku kulturowym antyku, wykorzystując jego żywą i inspirującą obecność.

Przytoczone uwagi łączą się z problemem znacznie szerszym i doniosłym, dotyczącym antyku postrzeganego w Europie przez wielu, w ciągu minionych stuleci jej dziejów, jako fundamentu jej cywilizacji ${ }^{5}$. Niemniej jednak, niektórzy współcześni archeolodzy klasyczni utrzymują, że takie spojrzenie na antyk jest niestosownym przeżytkiem, który tylko hamuje badania ${ }^{6}$. Jest to zagadnienie niezmiernie złożone, dotykające sporu o dziedzictwo europejskie, które dla jednych pozostaje niezbywalną wartością, do której należy wciąż nawiązywać i ją spożytkowywać, a dla innych przygniatającym ciężarem, niepozwalającym na zmiany i przekraczanie barier. Wspominam ów spór w kontekście rozważań dotyczących minionego i współczesnego charakteru archeologii klasycznej, ponieważ zagadnienie wagi dziedzictwa antyku w kulturze europejskiej zazębia się do pewnego stopnia z kwestią rozwoju i dziejów tej archeologii oraz jej udziału w refleksji nad sztuką starożytną, do czego odniosę się jeszcze w dalszej części tekstu.

\footnotetext{
${ }^{1}$ Lang 2002, s. 9.

${ }^{2}$ Cogita te missum in provinciam Achaiam, illam veram et meram Graeciam, in qua primum humanitas litterae, etiam fruges inventae esse creduntur; missum ad ordinandum statum liberarum civitatum, id est ad homines maxime homines, ad liberos maxime liberos, qui ius a natura datum virtute meritis amicitia, foedere denique et religione tenuerunt. Gaius Plinius Caecilius (Minor), Epist. 8.24. Cyt. za: http://www.thelatinlibrary. com/pliny.ep8.html [dostęp maj 2011].

${ }^{3}$ Meier 2009, s. 22, 23.

${ }^{4}$ Millett 2007, s. 31-33.

${ }^{5}$ Mrozewicz 2008, s. 13.

${ }^{6}$ Morris 2004, s. 256.
} 
Znanym nie tylko badaczom starożytności jest fakt, iż blask Grecji opromienił także świat rzymski, ale wydaje się, że nie odbywało się to jedynie na zasadzie przywłaszczania osiągnięć kulturowych, o czym wspomniałam już powyżej. Pomimo niejednokrotnie trudnych relacji rzymsko-greckich i często rabunkowego podchodzenia Rzymian do greckiej spuścizny kulturowej, wymiana zachodziła do pewnego stopnia na zasadzie nieprzymuszonej wzajemności. Co więcej, to ostatecznie właśnie dzięki pośrednictwu Rzymian kultura helleńska krzewiła się na różnych obszarach stworzonego przez tych pierwszych ogromnego imperium i tym samym została przekazana następnym okresom dziejowym. Można zatem powiedzieć, że już w starożytności dokonała się pierwsza na wielką skalę synteza złożonego dorobku kultury antycznej, która następnie oddziaływać będzie w głąb średniowiecznej i renesansowej Europy, a każda następna epoka kreować będzie swój własny model starożytności i dokonywać kolejnych interpretacji oraz syntez jej wielorakiego dorobku? ${ }^{7}$.

W okresie renesansu pojawił się prawdziwy entuzjazm dla specyficznych obszarów grecko-rzymskiej spuścizny, ze szczególnym uwzględnieniem architektury, rzeźby, malarstwa i rzemiosł artystycznych. Zaczęto wówczas dostrzegać coraz lepiej możliwość odnoszenia owych reliktów do współczesnych im źródeł pisanych, co dało efekt w postaci określonych zasad postępowania, które w czasach późniejszych spowodowały powstanie metod badawczych i umożliwiły rozwój archeologii klasycznej, a które niewątpliwie wyróżniają ją spośród wszystkich innych dziedzin archeologii. Pierwszeństwo miały źródła pisane, stąd ich zgłębianie stanowiło podstawę badań, a tzw. metoda filologiczno-historyczna pozostawała jako podstawowa do badania zabytków do końca XIX w. Nie dziwi więc fakt, że niektórzy uczeni, jak Eduard Gerhard, jeden z głównych założycieli Instituto di corrispondenza archeologica w Rzymie w 1829 r., nazywali archeologię monumentale Philologie, chcąc ją postawić na równi z tradycyjną filologią ${ }^{8}$. Zaznaczyć należy, iż funkcjonowanie rzymskiej placówki uwzględniać miało wszystkie wypracowane naówczas podejścia do starożytności, a była to zarówno XVIII-wieczna estetyka Johanna J. Winckelmanna, dynamicznie rozwijająca się w XIX stuleciu filologia klasyczna, jak również niezmiernie bogata tradycja oświeconych podróżników i kolekcjonerów ${ }^{9}$, przy czym następował wyraźny zwrot ku pozytywizmowi, mający przynieść narzędzia i zasady badawcze usamodzielniające archeologię. Powracając raz jeszcze do owej zaproponowanej przez Gerharda archeologii jako „filologii monumentalnej / monumentów”, należy zaznaczyć, iż był to pierwszy projekt, który uwzględnia-

\footnotetext{
${ }^{7}$ Por. wykład Profesora Tadeusza Kotuli „Starożytność wiecznie żywa”, wygłoszony w trakcie uroczystości wręczenia Uczonemu tytułu Doktora Honoris Causa Uniwersytetu im. Adama Mickiewicza w Poznaniu, w dniu 13 marca 2007 r. Źródło: strona internetowa Zakładu Historii Społeczeństw Antycznych w Instytucie Historii UAM - http://www.staff.amu.edu.pl/ zhsa/index.php?option=com_content\&task=view\&id=85 [dostęp maj 2011]. Zob. także: Thaddaeus Kotula. Doctor honoris causa Universitatis Studiorum Mickiewiczianae Posnaniensis 13 III 2007, Uniwersytet im. Adama Mickiewicza w Poznaniu, Poznań 2007.

${ }^{8}$ Gerhard 1850, s. 205; Lang 2002, s. 45.

${ }^{9}$ Dyson 2006, s. 31, 32.
} 
jąc wagę danych filologicznych, kładł nacisk przede wszystkim na materialne źródła starożytności, które jako samoistne powinny być poddawane szczegółowym badaniom i systematycznym publikacjom ${ }^{10}$.

Uzupełniając powyższe, wypada od razu zwrócić uwagę, iż archeologia klasyczna od początku jej naukowego zaistnienia w XIX w. nie odnosiła się w sposób bezpośredni tylko do jakiegoś regionu lub odcinka chronologicznego, jak to się działo w przypadku archeologii pradziejowych, i nie odnosiła się jedynie do źródeł materialnych (głównie starożytnych dzieł sztuki), które uzyskały status „klasycznych”. Była to archeologia, i taką nadal pozostaje, która wiązała się z szerszym pojęciem powstałym w toku rozwoju tzw. studiów klasycznych, dotyczących szeroko rozumianego „świata klasycznego”, terminu niezmiernie pojemnego. „Świat klasyczny” to przede wszystkim ten, po którym pozostały źródła literackie, jakie uzyskały status „klasycznych” w cywilizacji zachodniej. Określenie archeologia klasyczna głównie dotyczy takiego świata. Ma ona jednak również odniesienie czasowo-przestrzenne, swe historyczne granice, które większość badaczy widzi w obszarach zdominowanych przez Greków, a następnie Rzymian, pomiędzy VIII stuleciem p.n.e. a IV stuleciem n.e., przy czym podnoszona bywa też wyjątkowa umowność i problematyczność tak szeroko zakrojonych cezur ${ }^{11}$. Archeologia klasyczna jest archeologią tego świata ${ }^{12}$.

Powracając do kwestii początków nowożytnej refleksji nad antykiem w czasach renesansu, wypada zauważyć, iż to wspólne postrzeganie w obrębie późniejszej archeologii klasycznej zarówno Grecji, jak i Rzymu ma korzenie tamże, a wzięło się ze zrodzonego wówczas przekonania, utrwalonego w czasach późniejszych, o unikatowości świata greckiego i rzymskiego w historii Europy, który pozostawił obok innych dzieł wyjątkową ilość tekstów swej własnej kultury. Ponadto liczne artefakty antyczne, a przede wszystkim dzieła plastyki, zaczęły być postrzegane jako modelowe przykłady doskonałości, którą osiągnąć mogą wytwory człowieka. Ogólnie powiedzieć można, że począwszy od czasów renesansu, w Europie wyraźnie zauważono i zaczęto powszechnie uznawać, iż poziom rozwoju intelektualnego, jak również stopień konceptualizowania świata, jaki osiągnięty został $\mathrm{w}$ antyku, jest podstawą cywilizowanego życia. Warto jednak zwrócić uwagę, iż już w średniowieczu tzw. rewolucja „papieska” wieków XI-XIII według określenia Philippe'a Nemo wykorzystywała osiągnięcia nauki greckiej i prawa rzymskiego, wpisując biblijną etykę i eschatologię w porządek dziejów ${ }^{13}$. Owo uznanie dla osiągnięć antyku wraz z rozpowszechnieniem się chrześcijaństwa zaczęło być widziane jako fundament zachodniej cywilizacji, ale w jakimś stopniu wykorzystane zostało także w służbie zachodniego imperializmu, opartego na przekonaniu o ponadczasowym, uniwersalnym znaczeniu tych osiągnięć, zatem i na wartościującym przekonaniu

\footnotetext{
${ }^{10}$ Schnapp 2004, s. 171.

${ }^{11}$ Morris 2004, s. 257, 258.

${ }^{12}$ Osborne, Alcock 2007, s. 1.

${ }^{13}$ Nemo 2006, s. 11.
} 
o wyższości owego świata ${ }^{14}$. Stąd między innymi pojawiające się wśród badaczy o nastawieniu modernizującym i krytycznym dzisiejsze negatywne lub przynajmniej ambiwalentne oceny archeologii klasycznej, której historia splata się w pewnej mierze z postrzeganiem wyjątkowej roli świata klasycznego w dziejach cywilizacji europejskiej, na czym owa archeologia miała bazować, przyczyniając się do utrwalania tradycyjnego porządku $^{15}$. To miało też powodować, iż archeologia klasyczna w mniejszym stopniu awiąc o otwieraniu się na bieżące dyskursy toczone w obrębie nauk humanistycznych i społecznych, które mocniej oddziaływały na archeologię pradziejową ${ }^{16}$. Niemniej jednak James Whitley podkreśla dobitnie, iż jakkolwiek archeologia klasyczna długo nie przyjmowała w okresie po II wojnie światowej nowych teoretycznych trendów, które adaptowała archeologia prahistoryczna (na przykład wyjątkowo opornie ulegała nurtom procesualnym z kręgu tzw. New Archaeology), to z całą pewnością nie była nigdy nauką pozbawioną silnych podstaw teoretycznych, a jej głównym, w pełni zdefiniowanym i utrwalonym teoretycznym paradygmatem był ten, który można określić jako niemiecki „hellenizm" ", prąd myślowy zrodzony już w oświeceniu i trwający aż po wiek XX, o którym szerzej w dalszej części tekstu.

Warto od razu zaznaczyć, iż w obrębie takich współczesnych dyskursów naukowych, jak postmodernizm czy studia postkolonialne, które niejednokrotnie reprezentują podejścia radykalnie krytyczne (sądzę, że czasami jednostronnie ukazujące krytykowane zjawiska, bez prób wniknięcia w ich historyczną, złożoną perspektywę), uznaje się tradycyjne, obarczone ładunkiem wartościującym pojęcia „cywilizacja” oraz „klasyczny” za pejoratywne, które w takim rozumieniu nie powinny znajdować zastosowania ${ }^{18}$.

Jeśli chodzi o kolejne wątki złożonych dziejów archeologii klasycznej, nad którymi głębszy namysł pozwala dopiero zrozumieć, czym ona była kiedyś i czym jest dzisiaj ${ }^{19}$, wypada dobitnie zaznaczyć, iż niewątpliwie jest to archeologia nie tylko odkrytych na terenie świata klasycznego, a funkcjonujących w okresie jego historycznego rozwoju miejsc i pozostałości materialnych, ale także archeologia odnosząca się do znaczenia owych miejsc, uaktualnianego nieustannie w dziejach Europy. A owe pozostałości materialne (nie wspominając o pisanych), w tym szczególnie architektura i sztuka, obdarzone zostały w dziejach zachodniej kultury wyjątkowymi wartościami, które miały trwały wpływ na kształtowanie się europejskiej wrażliwości i sposobów postrzegania świata. Sądzę, że uprawnione jest więc stwierdzenie, że spuścizna klasyczna jest własną przeszłością całej Europy (i na tej zasadzie archeologia klasyczna jest własną archeologią

\footnotetext{
${ }^{14}$ Dyson 2006, s. XIV; Osborne, Alcock 2007, s. 2.

${ }^{15}$ Whitley 2001, s. 10; Morris 2004, s. 256.

${ }^{16}$ Renfrew 1980, s. 290-295; Snodgrass 1985, s. 31-37; Dyson 1993, s. 195, 196; Whitley 2001, s. $12-16$.

${ }^{17}$ Whitley 2001, s. 16.

${ }^{18}$ Por. np. omówienie przez Jonathana Harrisa w książce Art History. The Key Concepts terminów civilisation, civilised, civilising, civil, civilian, uncivil oraz classical/class, classic, classy (Ha r r is 2006, s. 51-54).

${ }^{19}$ Lang 2002, s. 41-73.
} 
wszystkich tych krajów europejskich, które się do niej odwołują), bez względu na to, w jakim zakresie prahistoria również tą przeszłość tworzy i w jakim tworzą ją także archeologie poszczególnych regionów i ludów, które mieszkały w zdecydowanej większości poza światem klasycznym ${ }^{20}$. W ten sposób archeologia klasyczna przez długi czas swego rozwoju zajmowała pozycję wyjątkowo uprzywilejowaną, a ponadto ona także do pewnego stopnia, podobnie jak studia klasyczne, nie tylko zajmowała się zgłębianiem starożytnej przeszłości, ale miała odczytywać i przekazywać wypracowane w świecie antycznym wartości kolejnym generacjom ${ }^{21}$. A były to głównie wartości wypływające z koncepcji „hellenizmu”, prądu myślowego i estetycznego wypracowanego w nowożytności, w 2. poł. XVIII stulecia i rozwijanego w XIX, w kręgu myślicieli niemieckich, szybko rozpowszechnionego po całej Europie. Według tej koncepcji przeszłość grecka stanowiła kwintesencję tego, co najlepsze w dziejach ludzkości i niedościgniony ideał, do którego należy dążyć. Na gruncie sztuk pięknych na przykład antyk dla ludzi końca XVIII w. stał się ponadczasowym, najwyższym ideałem piękna, przeciwstawianym współczesności. Ani renesans, ani barok nie znały w tym stopniu zasady naśladowania dzieł starożytnych, jaka pojawia się w klasycyzmie. Postulowało się wówczas w wielu regionach Europy dążenie do wspólnoty wykształcenia, jakąś równość smaku, wiedzy i talentu - wszystko oparte na nawrocie do antyku ${ }^{22}$. Takie zauroczenie kulturą Hellady, w której odkryto niewyczerpane źródło inspiracji dla własnej twórczości i refleksji, dzielili pospołu pisarze i artyści oświecenia, jak i romantycy oraz twórcy i myśliciele późniejsi, a błędem byłoby myśleć, że naukowe podejście pozytywistyczne wyrugowało romantyczny „,hellenizm” - on trwał. „Helleńskość” w tym wydaniu, jak wskazują badania współczesne, była bardzo sugestywna i ulegała wyjątkowej mitologizacji. W uzupełnieniu należy podkreślić, powracając do wiodącego niemieckiego ,hellenizmu”, iż tak samo istotny jak apologetyczny był również jego polemiczny aspekt, wymierzony przede wszystkim w klasycyzm francuski, i w ogóle wcześniejszą nowożytną recepcję antyku, zapoczątkowaną renesansowym humanizmem. Jądrem „hellenizmu” niemieckiego było powszechne przekonanie jego reprezentantów, że tylko oni odnaleźli prawdziwego „ducha” Grecji i greckiego artyzmu ${ }^{23}$. W takim kontekście kulturowym rozwijają się studia klasyczne (a przy okazji archeologia klasyczna), a niewątpliwie Niemcy skupiają przodujące ośrodki studiów filologicznych nad literaturą grecką i dochodzą na tym polu do niezaprzeczalnych osiągnięć. Co więcej, postulowanym podejściem badawczym jest Totalitätideal der Altertumswissenschaft, czyli pełne opanowanie wiedzy o starożytności za pomocą wszystkich dostępnych źróde ${ }^{24}$. Można stwierdzić, iż takie zaangażowane, skrupulatne studia nad grecką starożytnością, rozpowszechniające się po

\footnotetext{
${ }^{20}$ Osborne, Alcock 2007, s. 2.

${ }^{21}$ Whitley 2001, s. 11, 12.

${ }^{22}$ Białostocki 1976, s. 124, 125.

${ }^{23}$ Whitley 2001, s. 32-34.

${ }^{24}$ Dys on 2006, s. 31 .
} 
całej Europie i w USA, szczególnie w XIX w., stanowiły także zaplecze intelektualne rozwoju archeologii klasycznej ${ }^{25}$.

Nie tylko jednak wspomniane studia stały się powodem rozwoju archeologii klasycznej, ale również inne okoliczności, które wydają się bezpośrednim impulsem do jej zaistnienia. Zadecydowały przy tym o jej niezależnej drodze i specyficznym charakterze, wyróżniającym ją spośród pozostałych gałęzi archeologii. Z jednej strony jest to stosunkowo duża liczba antycznych dzieł sztuki, jak również świątyń oraz innych budowli, która dotrwała do czasów nowożytnych, z drugiej - opisy kwitnących ośrodków starożytnych znane z literatury klasycznej, których zaczęto intensywnie poszukiwać w terenie, a szczególnie po spektakularnych odkryciach na terenie Kampanii. Począwszy zatem już od XVIII w., nowe zabytki oraz stanowiska coraz liczniej zaczęły się ujawniaćéc. Ta spuścizna - a właściwie jej ogrom i walory estetyczne spowodowały ukierunkowanie archeologii klasycznej na badania sztuki i architektury, jak również brak szerszego zainteresowania innymi pozostałościami kultury materialnej starożytności, które nie wydawały się aż tak godne refleksji naukowej. $Z$ drugiej strony ogromna liczba starożytnych źródeł pisanych, w tym przede wszystkim licznych inskrypcji, wyniosła archeologię klasyczną na uprzywilejowaną pozycję w stosunku do archeologii społeczności prahistorycznych, a owe źródła pisane, stawiane zawsze, jak już to powyżej zostało podkreślone, na pozycji prymarnej wobec materialnych, które tylko „ilustrowały” te pierwsze, uważano przez długi czas niemal bezkrytycznie za „,autentyczny wgląd” w świat starożytny.

Zatrzymując się jeszcze na okolicznościach powstania i rozwoju archeologii klasycznej, mającej od początku do czynienia z imponującą spuścizną dobrze zachowanych starożytnych reliktów materialnych, w tym dzieł sztuki, można zauważyć, że zarówno archeologia, jak i historia sztuki mają wspólne początki. Obie zaczęły się z wolna wyłaniać w ciągu XVIII w., jako część tego samego procesu, zastępującego amatorską tradycję antykwarycznych poszukiwań - kolekcjonerstwa, znawstwa oraz rozmaitych odmian starożytnictwa, aby ostatecznie ukonstytuować się jako nowoczesne, akademickie dyscypliny naukowe $\mathrm{w}$ ostatnich dekadach wieku XIX i pierwszych XX, opierając się na paradygmacie klasyfikacyjno-chronologicznym (pierwsza) oraz stylistycznym (druga). Kluczową postacią owej zmiany był już w XVIII stuleciu wspomniany J. J. Winckelmann, który odniósł starożytne źródła literackie dotyczące rozwoju rzeźby antycznej do pozostałości, które przetrwały w Rzymie. Warto wspomnieć, że świat sztuki starożytnej widziany był uprzednio jako monolit, bez perspektywy historycznej, czyli możliwości ulokowania dzieł według ich następstwa, w czasie Winckelmann taką perspektywę im

\footnotetext{
${ }^{25}$ Najszerzej oraz najbardziej krytycznie na temat idei niemieckiego „hellenizmu”, mającego stanowić wyłączne korzenie „europejskości”, a także jej negatywnego wpływu na archeologię Grecji, wypowiada się Ian Morris (1994, s. 8-47 oraz 2004). Sugeruje się obecnie czasami także omijanie tego wieloznacznego terminu który, podobnie jak „orientalizm”, wykreowany został w określonym kontekście historycznym i może sugerować imperializm kulturowy, por. The Oxford Dictionary of the Classical World, ed. J. Roberts, 2005, s. 329, termin hellenism, hellenization.

${ }^{26} \mathrm{Sch}$ aps 2011 , s. 178.
} 
nadal ${ }^{27}$. Interesowały go przy tym bardziej same dzieła niż biografie artystów, a pytając o przyczyny zróżnicowania ich stylów, dawał odpowiedzi wielostronne, biorąc pod uwagę umiejętności techniczne, uwarunkowania historyczne i geograficzne, wyrażane treści, a nawet postawy moralne odbiorców. Wykorzystał pojęcie stylu, którym operował ujmując jego cechy ze względu na historyczną zmienność. Niemniej paraboliczny model, który zaproponował (styl archaiczny, rozwinięty, piękny i naśladowczy - der ältere Stil, der hohe Stil, der schöne Stil, der Stil der Nachahmer), uznając za wzór i normę grecką sztukę klasyczną oraz podnosząc ją do rangi absolutu, a tym samym mitologizując i wyłączając z procesu historycznego, mocno zaważył na postrzeganiu rozwoju sztuki w ogóle ${ }^{28}$. Zenit ludzkich osiągnięć artystycznych łączył się według Winckelmanna z okresem charakteryzującym się rozwojem wolności i demokracji, a wyjątkowość Greków przejawiła się w umiejętności wybierania i adaptowania najbardziej perfekcyjnych form natury, wedle schematu imitacyjnego i tworzenia z nich idealnych całości ${ }^{29}$. Winckelmann, zwracając się do sobie współczesnych, twierdził, iż „,... jedyną dla nas drogą, by stać się wielkimi, jeśli to w ogóle możliwe, jest naśladowanie antyku”30.

Na gruncie archeologii klasycznej, która stała się w dużej mierze tożsama z historią sztuki starożytnej, zaczęto rozróżniać pomiędzy dziełami, właściwymi dla rozważań toczonych na kanwie estetycznej, a zwykłymi artefaktami, które nie zasługiwały na bliższą uwagę. Rozróżnienie czyniono na postawie poziomu technicznego wykonania dzieł, ich oddziaływania estetycznego oraz walorów artystycznych, mających ujawniać cechy swoiste wyobraźni greckiej, rzymskiej czy egipskiej. Zgodnie z tym modelem antyczna waza została podniesiona do rangi dzieła sztuki, tym bardziej, kiedy odkryto na niej sygnatury wykonawców i malarzy. Co więcej, przedstawione sceny, a przede wszystkim styl ich wykonania, zaczął służyć jako źródło do poznania niezachowanego, antycznego malarstwa monumentalnego, opisywanego w starożytnych przekazach pisanych. Pojawiły się szczególne metody badań, głównie koneserskich, takie jak atrybucjonizm, wyjątkowo rozwinięty w wydaniu Adolfa Furtwänglera i studiów nad gemmami, a przede wszystkim rzeźbą, jak również Johna D. Beazleya i studiów nad malarstwem wazowym ${ }^{31}$. Powiązania archeologii klasycznej $z$ historią sztuki były bardzo liczne, a wśród wspólnych orientacji badawczych najbardziej doniosłe i trwałe okazały się kwestie analizy formalnej i stylistycznej oraz metoda ikonograficzno-ikonologiczna ${ }^{32}$, aczkolwiek i inne podejścia badawcze, polegające głównie na szerszym wykorzystaniu metod semantycznych, jak również na badaniu strategii reprezentacji, znalazły także

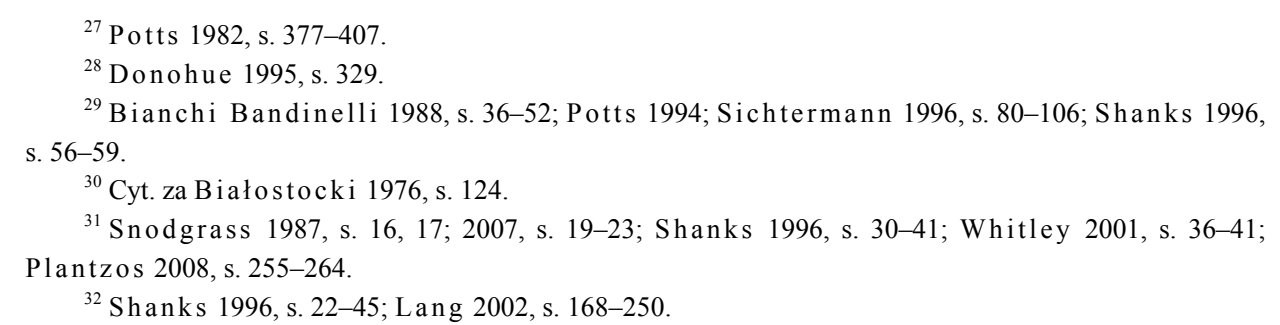


swe miejsce na gruncie archeologii klasycznej i były oraz są z powodzeniem wykorzystywane $^{33}$.

W miarę rozwoju obu dyscyplin odmienne metody postępowania badawczego jednak coraz częściej się ujawniały, a ścieżki naukowe rozchodzić się zaczęły wyraźnie w 2. poł. XX w. Stwierdzić można, iż rozbieżności w postępowaniu badawczym archeologów klasycznych i historyków sztuki rosły wraz z uświadamianiem sobie odmienności źródeł zwyczajowo badanych przez przedstawicieli wspomnianych dyscyplin, a ponadto wynikały z innego odniesienia historyków sztuki oraz archeologów do świata dzieł czy artefaktów, pozostającego na zewnątrz studiów akademickich. Chodzi tutaj o fakt, że wielu historyków sztuki miewało i miewa liczne powiązania z rynkiem sztuki oraz wszelkimi działaniami eksperckimi na tym polu, co w równej mierze przez dziesiątki lat dotyczyło też archeologów klasycznych. Niemniej jednak w ramach kształcenia w zakresie historii sztuki promowane bywają do dzisiaj profile koneserskie i najczęściej nie wykracza to poza standardy uprawiania tego zawodu oraz nie powoduje utraty historycznych wartości dzieł. W przypadku archeologii i handlu starożytnościami jest z reguły odwrotnie, a działania takie, najczęściej nielegalne, doprowadzają do niszczenia stanowisk oraz ich grabieży i bezpowrotnej utraty danych źródłowych dla nauki. Stąd w ostatnich latach zaczęto szczególnie negatywnie odnosić się do rozciągania na obiekty archeologiczne założeń wiązanych ze znaczeniami i przesłaniami tkwiącymi w nowożytnej koncepcji sztuki, która pozostaje autonomiczną sferą estetycznej kontemplacji lub ekspresją wyobraźni kreatywnych jednostek. Ostrze krytyki zwrócono też w kierunku muzeów, których starożytne kolekcje zasadniczo tworzone są na podstawie estetycznych walorów zgromadzonych tam obiektów, traktowanych jako dzieła sztuki wyrwane zupełnie $\mathrm{z}$ kontekstów kulturowych, w których powstały i funkcjonowały. W środowisku archeologicznym zaczęto upominać się o szerszy udział lub wręcz odgrywanie kluczowej roli w podejmowaniu prób zrozumienia i interpretacji starożytnych źródeł materialnych, do których zaliczyć należy starożytne dzieła sztuki, aby w ten sposób próbować je wydobyć z ram, w których wartość estetyczna i rynkowa są wiodące ${ }^{34}$.

Kwestia ta ma również wymiar bardziej ogólny, dotyczący zasad prezentowania dzieł w różnych typach muzeów oraz w ogóle roli muzeów we współczesnym świecie. W muzeach archeologicznych bądź antropologicznych stosowane są od jakiegoś czasu określone tryby prezentowania artefaktów kulturowych. Obecnie najczęstsze są ujęcia kontekstualne i typologiczne, często uzupełniane próbami wprowadzenia tzw. wewnętrznego punktu widzenia, czyli dążeniem do ukazania kultury z punktu widzenia jej domniemanych bądź rzeczywistych przedstawicieli, więc mnożą się wizualne projekcje konkretnego bytowania ludzi w starożytności, bądź w swej grupie plemiennej. Ujęcia formalne lub estetyczne, traktowane jako zupełne przeciwieństwo kontekstualizmu,

\footnotetext{
${ }^{33}$ Hö1scher 2000, s. 147-165; Bergmann 2000, s. 166-188.

${ }^{34}$ Shanks 1996, s. 59-65; Chippindale, Gill 2000, s. 463-511; Scott 2006, s. 628, 629; Dyson 2006, s. 224-228.
} 
uważa się za bardziej stosowne dla galerii sztuki ${ }^{35}$. Z drugiej strony niektórzy badacze wskazują, że muzea wszelkiego rodzaju w tradycji europejskiej miały ponad wszystko jedną wspólną, długą historię i cel, aktualny też dzisiaj - a mianowicie zwracania uwagi na sam prezentowany przedmiot, obiekt, dzieło, jako wizualny wytwór, którego istnienie (powstanie) wiąże się ze zręcznością, jakimś twórczym procesem (także zachodzącym w naturze), bez względu na to, jak pisze Svetlana Alpers, czy mamy do czynienia z krabem, czy z rzeźbą grecką niegdyś będącą statuą kultową w świątyni bądź na stadionie. Muzea zatem w nieunikniony sposób zmieniają wszelkie obiekty w dzieła sztuki, efekt estetyzacji zachodzi, stąd pozostają miejscami, gdzie przede wszystkim promowane są sposoby widzenia ${ }^{36}$.

Jeśli chodzi o pozyskiwanie w naszych czasach starożytności do kolekcji muzealnych, $\mathrm{z}$ unikaniem wszelkich form wandalizmu kulturowego, którego synonimem stał się „elginizm” oraz udział w tym procederze archeologów, debata międzynarodowa na ten temat nigdy nie była aż tak ożywiona jak w ostatnich latach, a szczególnie aktualizuje się w obliczu konfliktów zbrojnych i plądrowania znaczących kolekcji, na przykład tej w Bagdadzie ${ }^{37}$. Do tego dochodzą istotne ostatnio z wielorakich pobudek, bardzo złożone kwestie restytucji dóbr kultury zagrabionych $w$ czasach minionych ${ }^{38}$. Coraz częściej podnoszona bywa także trwająca w USA (ale również i w wielu innych krajach świata) praktyka zakupowania dzieł starożytnych pozbawionych proweniencji przez znaczące instytucje muzealne, kiedy od wielu lat trwają zabiegi zmierzające w kierunku prohibicji międzynarodowego handlu starożytnościami. Ze strony muzeów z kolei pojawiają się argumenty, iż prywatnych kolekcjonerów nie uda się powstrzymać, natomiast muzea, uczestnicząc w takim handlu, do pewnego stopnia są w stanie „kontrolować” sytuację oraz upubliczniać informacje o pozyskiwanych artefaktach ${ }^{39}$.

Wreszcie, przy okazji wzmiankowanych kwestii, warto zwrócić uwagę krótko na jeszcze jeden problem, a mianowicie na zbiory artefaktów archeologicznych, korpusy dzieł, które przecież same w sobie są ,produktem” pracy badawczej archeologów, powstałym na bazie przyjętych kryteriów, z bardzo wybiórczo zachowujących się szczątków odległej przeszłości. Owe zbiory źródeł archeologicznych w obiegu publicznym niejednokrotnie nabierają cech prawie metafizycznych, tzn. zaczynają być postrzegane jako skończone, całościowe, jakby celowo powierzone nam przez ludzi z przeszłości w celu zachowania, ochrony i przekazywania kolejnym generacjom. Pojawia się tutaj kwestia etycznej odpowiedzialności za prowadzone badania oraz konieczności upubliczniania także wiedzy, iż zbiory źródeł archeologicznych są efektem praktyk i metod ba-

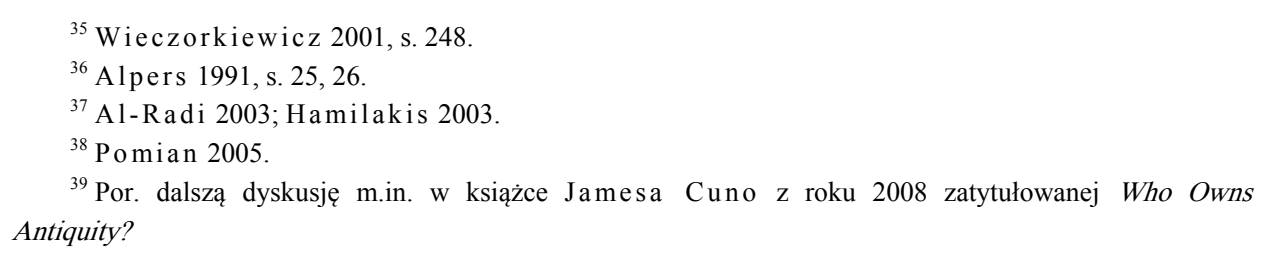


dawczych mających zastosowanie w tej dyscyplinie, które poddawane być muszą stałej weryfikacji ${ }^{40}$.

Problemy sygnalizowane powyżej na podstawie wybranych wątków, ale uznawanych za najistotniejsze dla rozważań na temat powiązań archeologii klasycznej z historią sztuki, poświadczają wystarczająco moim zdaniem zarówno bliskie, jak i złożone relacje obu dyscyplin. Owe relacje, a przede wszystkim krytykowane coraz mocniej w ostatnich dekadach XX w. zdominowanie archeologii klasycznej przez długi czas badaniami rzeźby, czy malarstwa, więc artefaktów uznanych za wyjątkowe, które specyficzny status dzieł sztuki uzyskały w nowożytnej kulturze europejskiej, a konkretnie dopiero w XVIII w., spowodowały, iż współczesna archeologia klasyczna, przeformułowując słusznie swe pola badawcze zupełnie niepotrzebnie rezygnuje niejednokrotnie $\mathrm{z}$ kontynuowania badań w zakresie historii sztuki starożytnej. Podkreślić należy, iż rezygnuje tym samym z dorobku wypracowywanego w ciągu już prawie dwustu lat jej funkcjonowania przez różnorodne tradycje intelektualne wielu narodów, które ją uprawiały ${ }^{41}$. Sądzę, zgadzając się tym samym z uwagami Jamesa Whitleya, zawartymi w tekstach tegoż autora na temat podejść badawczych historii sztuki i archeologii, iż nikła znajomość wśród badaczy anglosaskich, mających w ostatnich dekadach znaczny wpływ na debatę ogólną na polu archeologii, doniosłego dorobku archeologii kontynentalnej, w tym szczególnie niemieckiej, sprawia, iż studia te bywają wyjątkowo jednostronne, a wszelkie zabytki czy artefakty postrzegane $\mathrm{i}$ interpretowane są jedynie jako materialne ślady ideologicznych manipulacji, głównie związanych z relacjami władzy ${ }^{42}$.

Uważam, że unikanie $\mathrm{w}$ ostatnich latach badań prowadzonych $\mathrm{z}$ pozycji historii sztuki, wcześniej stale w mniejszym lub większym stopniu obecnych na polu archeologii klasycznej, jest jej wielkim zubożeniem oraz odcięciem się od inspirującego źródła wspaniałej tradycji, która wydała setki wartościowych prac. Co więcej, odchodzenie od takich badań jest tym bardziej niezrozumiałe dzisiaj, w sytuacji, kiedy historia sztuki, antropologia kultury czy tzw. visual studies, każda w odmienny sposób, mierząc się ze współczesną globalizacją świata obrazów i akcentując transkulturową wspólnotę w ludzkim obcowaniu z obrazami, stawiają sobie cele poznawcze docierania do sensów artefaktów wizualnych innych epok i kultur ${ }^{43}$. Archeologia klasyczna nie powinna zaprzestawać również działań na tym polu. Sądzę ponadto, że utożsamianie archeologii

\footnotetext{
${ }^{40}$ Hamilakis 2003, s. 107.

${ }^{41}$ Por. przywoływany w niniejszym tekście, napisany ostatnio przez liczne grono wybitnych specjalistów, podręcznik archeologii klasycznej (Alcock, O sborne red. 2007), w którym jednak nie znalazło się odrębne miejsce na rozdział dotyczący badań starożytnej sztuki, czy jak to bywa obecnie nazywane - kultury wizualnej, i nie znalazł się autor, który chciałby się odnieść do istniejącego na tym polu dorobku.

${ }^{42}$ Whitley 1987 , s. 9-15; 1993, s. 27, 28. Warto porównać szczególnie uwagi autora zawarte we wcześniejszym z wymienionych artykułów, w którym kładzie nacisk na konieczność poznania wielkiego wpływu niemieckiej filozofii idealistycznej na rozwój kontynentalnej, a szczególnie niemieckiej archeologii klasycznej i historii sztuki oraz dorobku naukowego, który z tego się zrodził.

${ }^{43}$ Belting 2007.
} 
klasycznej z historią sztuki starożytnej, co miało według obiegowych opinii niektórych prahistoryków, między innymi powodować jej „,zacofanie” oraz małą podatność na aplikowanie teorii, przenikających na grunt archeologii pradziejowej swobodnie, nie jest uprawnione. Problem ów z pewnością wymagałby pogłębienia badań nad nim, ale akcentując jedynie wspominane powyżej kwestie silnych powiązań archeologii klasycznej $\mathrm{z}$ historią sztuki, wystarczy nadmienić, że ta druga na bieżąco w debatach teoretycznych uczestniczyła i uczestniczy, czerpiąc z nich inspiracje i aplikując do swych studiów ${ }^{44}$. Wydaje się, że archeolodzy klasyczni w pewnym momencie swego rozwoju niepotrzebnie oddzielili się od historii sztuki (podobnie zresztą od historii), podczas gdy we wczesnych ich pracach, jak podkreśla Alain Schnapp, widać wyraźne inspiracje refleksją teoretyczną, a książki te pozostają swoistą fenomenologią sztuki lub historiami ludzkich osiągnięć wraz z nieodzownymi interpretacjami tychże ${ }^{45}$.

To, od czego archeologia klasyczna nie odstępowała, to skupianie uwagi na studiowaniu elitarnych, zachowanych tekstów starożytnych, poprzez które chciano „dotrzeć” do samych dzieł lub miejsc. Ponadto badacze angażowali się przez cały wiek XIX i większą część XX głównie w ogromne, wymagające świetnego zorganizowania wykopaliska na ważnych stanowiskach w świecie śródziemnomorskim, co pociągało za sobą konieczność opisywania i katalogowania niezmiernie licznych odkryć i znalezisk oraz powodowało wąskie specjalizacje, jak również fragmentacje wszelkich badań i poczynań. Mnożyć zaczęły się katalogi źródeł oraz wydawnictwa wyspecjalizowane w raportach wykopaliskowych. To mogło rodzić przekonanie, iż uogólnienia oraz podejmowanie nowych problemów badawczych czynione być mogą tylko na podstawie wcześniej opracowanych, specjalistycznych kompendiów źródeł, na podłożu solidnych i systematycznych zbiorów, a prawdopodobnie było to jeszcze pokłosiem oświeceniowych koncepcji rodem z początków dyscypliny, utrwalonych przez późniejsze pozytywistyczne nastawienie do nauki i nie sprzyjało otwieraniu się na nowe prądy oraz refleksji nad konceptualizowaniem wiedzy ${ }^{46}$.

Stąd archeologia klasyczna pozostawała w wyjątkowy sposób ukierunkowana wyłącznie na źródła, na obiekty, była archeologią, którą rządzą rozmaite typy i klasy dzieł, a nie archeologią ukierunkowaną na procesy i problemy, co od lat 80 . XX w. wyraźnie uległo zmianie. Ponad sto kilkadziesiąt lat tradycji takich badań doprowadziło do niezmiernego ugruntowania wiedzy źródłoznawczej, zabytkoznawczej, rozwiniętej w sposób koneserski - z reguły badacze nie mają trudności, aby stwierdzić, czym dany obiekt

\footnotetext{
${ }^{44}$ Literatura $\mathrm{z}$ tego zakresu jest ogromna, polecam zapoznanie się na przykład z bardzo obszerną pracą pióra Mariusza Bryla (2008), gruntownie omawiającą problem osadzenia historii sztuki w różnorodnych nurtach teoretycznych i debatach współczesnej humanistyki.

${ }^{45}$ S chnapp 1998; 2002, s. 134, 135. Badacz, w drugim z cytowanych tekstów, na poparcie tezy o odwoływaniu się do refleksji teoretycznej we wczesnych pracach archeologicznych przywołuje m.in. takie książki, jak C. O. Müllera 1830, Handbuch der Archäologie der Kunst, Breslau oraz C. B. Stracka 1880, Systematik und Geschichte der Archäologie der Kunst, Leipzig.

${ }^{46}$ Snodgrass 1987, s. 1-35; Dyson 1993, s. 195; Carstens 2004, s. 13.
} 
jest, skąd pochodzi, jak został wykonany oraz jak go datować. Ale prowadzenie badań to stawianie problemów, a nie opisywanie i analizowanie przedmiotów, nawet jeżeli etap źródłoznawczy uznajemy za bardzo ważny lub wręcz nieodzowny. Dzisiaj archeologia klasyczna pyta więc, jakie wzorce ludzkich zachowań są odciśnięte w artefaktach oraz na badanych stanowiskach, w jaki sposób odczytywać źródła jako świadków życia społecznego, religijnego i politycznego starożytnych społeczności Grecji i Rzymu, w jaki sposób możemy wyjaśnić dystrybucję rozmaitych wyrobów, czym było spowodowane rozprzestrzenianie się stylów artystycznych, mód i sposobów wykonywania dzieł itd. ${ }^{47}$

Po powyższych uwagach zwięźle odnoszących się do wybranych aspektów kontekstu kulturowego, w którego ramach zachodziło wyłonienie się archeologii klasycznej jako dyscypliny naukowej oraz bardzo złożonych jej relacji z historią sztuki, pragnę jeszcze zasygnalizować kilka innych, równie ważnych, moim zdaniem, wątków związanych z historią owej archeologii oraz jej usytuowaniem w obrębie dyscypliny.

Wypada zauważyć, iż kultura antyczna, a przede wszystkim literatura, była w Europie nowożytnej przez wieki bardzo ważnym źródłem idei, a w wielu krajach z czasem funkcjonować zaczęła jako podstawa idealnego wykształcenia humanistycznego, co szczególnie upowszechniło się w XIX w. Wyjątkową formę przybrały owe zjawiska w przywoływanych już tutaj wielokrotnie Niemczech ${ }^{48}$, gdzie podziw dla klasycznej kultury, głównie greckiej, znalazł odzwierciedlenie m.in. w nurcie zwanym „,neohumanizmem", którego wybitni przedstawiciele, tacy jak Wilhelm von Humboldt, lansowali nawet reformę szkolnictwa, poczynając od poziomu średniego, zmierzającą do powszechnego wprowadzenia tzw. gimnazjum humanistycznego ${ }^{49}$. Cele reformy były wzniosłe, a nauczanie rozumiano jako misję kształtowania człowieka. Jednak nastawienie kształcenia przede wszystkim na kulturę klasyczną i sztukę grecką (to znaczy ówczesny jej obraz i odczytywanie), czemu towarzyszyło spychanie na dalszy plan nauczania umiejętności praktycznych, jak również zainteresowania kulturą i sztuką swych czasów, prowadziło do odrywania edukacji od związków z ówczesną praktyką społeczną ${ }^{50}$. Niewątpliwie o wiele większą zasługą Humboldta, która na trwale wpisała się w organizację życia naukowego w Niemczech, a poniekąd i w znacznej części Europy, było konceptualne przygotowanie i faktyczne utworzenie uniwersytetu w Berlinie w 1810 r., z naczelną ideą koniecznej na poziomie uniwersyteckim jedności nauczania i badań ${ }^{51}$.

Uogólniając to, co powyżej wspomniano o Niemczech i nawiązywaniu tam do kultury klasycznej w szkolnictwie, szczególnie począwszy od wieku XIX, można zauwa-

\footnotetext{
${ }^{47}$ Osborne, Alcock 2007, s. 3 .

${ }^{48} \mathrm{~W}$ ciągu XIX w. uczeni niemieccy przekształcili w rzeczywistości studia klasyczne z amatorskich zajęć przeznaczonych dla duchownych i arystokratów, którymi wcześniej w dużej mierze były, w profesjonalne, osadzone w strukturach uniwersyteckich badania - tzw. Altertumswissenschaft. W owym stuleciu wiodąca rola badaczy niemieckich na polu studiów klasycznych, włączając w to archeologię, była niekwestionowana - por. Whitley 2001, s. 32-36.

${ }^{49}$ Lang 2002, s. 46.

${ }^{50}$ Andrzejewski 1989, s. 113-114.

${ }^{51}$ Ut supra, s. 241.
} 
żyć, że również w wielu innych krajach Europy kultura klasyczna bardzo długo pozostawała podstawą wykształcenia elit i integralną częścią życia społecznego, a ponadto stała się nawet częścią życia politycznego ${ }^{52}$, co z pewnością uprzywilejowało i nobilitowało studia klasyczne. Rozwój zainteresowań kulturą klasyczną (a w jej ramach także archeologią) w Europie na przełomie XVIII i XIX w., utrwalony w XIX stuleciu, i kontynuowany zresztą wciąż w pierwszych dekadach wieku XX, szedł także w parze ze wzrastającą identyfikacją polityczną i narodową. Szczególnym przykładem jest na tym polu Grecja, która wyzwoliwszy się spod panowania otomańskiego, całkowicie zwróciła się ku historii epoki Peryklesa ${ }^{53}$. Kolejnym przykładem są Włochy, aczkolwiek kraj ten w wyjątkowo ekstremalny sposób wykorzystał przeszłość klasyczną dopiero w latach 20. i 30. XX w., kiedy podniesiona do rangi ideału historia rzymska, a szczególnie okres panowania Augusta, stała się centralną dla konstrukcji politycznej ideologii czasów Mussoliniego ${ }^{54}$. Co więcej, wypracowana wówczas selektywna koncepcja „rzymskości” - romanità - odnoszona przede wszystkim do historii okresu cesarskiego, będąca elementem faszystowskiej propagandy, miała podkreślać młodość, rewolucyjność i zmysł modernizatorski w budowaniu nowej i pełnej wigoru Italii, z włączeniem w to najlepszych osiągnięć starożytnych. Prawdziwym języczkiem u wagi duce stał się Rzym, w którym w równym stopniu zaczęto prowadzić badania i zabezpieczać starożytności, a Mussolini był komplementowany za umożliwienie „triumfu archeologii nad znaczącymi siłami interesów ekonomicznych" "55, jak i z drugiej strony miasto ulegało bardzo radykalnej przebudowie oraz modernizacji, zupełnie bez poszanowania substancji zabytkowej, którą w dużym stopniu zniszczono.

Ale problem wykorzystania klasycznej przeszłości nie dotyczył tylko państw, na których terenie ostatecznie starożytne osadnictwo greckie i rzymskie miało utrwalone miejsce. Rozwijanie archeologii klasycznej w XIX w. było także podyktowane m.in. pragnieniem kulturowej rywalizacji pomiędzy znaczącymi siłami w Europie oraz w USA. Stąd w tym stuleciu wykształcenie na polu klasycznym należało wciąż do zasadniczych elementów wykształcenia elit rządzących w ogóle; tak było m.in. i w wiktoriańskiej Anglii, i w kolonialnej Ameryce, a w Europie trwało w Niemczech również i w czasach Trzeciej Rzeszy ${ }^{56}$. Taka międzynarodowa rywalizacja kryła się także do jakiegoś stopnia za znaczącym rozwojem kolekcji muzealnych, za udostępnianiem i popularyzowaniem zbiorów kolekcji prywatnych oraz sponsorowaniem wielkich wykopalisk, którymi miały być głównie miejsca znaczące i sławne już w starożytności.

\footnotetext{
${ }^{52}$ Lang 2002, s. 46.

${ }^{53}$ Whitley 2001, s. 30. Problem powiązań i uwikłania Grecji, także tej dzisiejszej, w swą starożytną przeszłość, szeroko omówiony został w pogłębionym i zniuansowanym ujęciu autorstwa Yannis a Hamilakisa (2007).

${ }^{54}$ Zanker 1999, s. 5.

${ }^{55}$ Cyt. za Painter 2005, s. 9; w książce odwołania do źródeł z tych czasów.

${ }^{56}$ Schaps 2011, s. 362.
} 
Na przykład badana wykopaliskowo starożytna Olimpia stała się szybko symbolem interesów niemieckich, Delfy francuskich, Knossos brytyjskich, a ateńska agora amerykańskich $^{57}$.

Można powiedzieć za Ianem Morrisem, że w tym okresie archeologia pradziejowa, również pozostająca w pewnej mierze „na usługach” rozmaitych państw narodowych, przekazywała swym społecznościom wiedzę o tym, co „leży u podstaw” bycia Duńczykiem, Niemcem lub Francuzem, ale archeologia klasyczna mówiła im wszystkim, co to znaczy być człowiekiem uosabiającym najlepsze cechy, możliwe do osiągnięcia na podstawie wzorowania się na starożytnych ${ }^{58}$. Starożytność klasyczna pozostawała epoką wzorcową w dziejach Europy długo, aczkolwiek powyższe stwierdzenie z pewnością upraszcza, na potrzeby niniejszego przeglądu, o wiele bardziej złożony obraz postrzegania i wykorzystywania przeszłości w ogóle oraz budowania wiedzy o niej. Już co najmniej od oświecenia następowała powolna afirmacja wartości odrębnych epok i charakterów etnicznych, która $\mathrm{z}$ wolna prowadziła w określonych przypadkach do kwestionowania uniwersalnie obowiązującej mocy antycznego wzorca i kierowała zainteresowania ku innym dokonaniom, na przykład ku sztuce średniowiecza. Procesy te znacznie się pogłębiły w kolejnych czasach ${ }^{59}$. Pomijam tutaj także szeroko rozważany w literaturze problem równoległego wykorzystywania lokalnej przeszłości i konstruowania pożądanego jej obrazu dla celów nacjonalistycznych w ramach narodowych archeologii pradziejowych - a chcąc to jedynie krótko zilustrować, wystarczy wspomnieć takie XIX-wieczne zjawiska, jak ,przywłaszczenie” przez Francuzów Karola Wielkiego oraz „wskrzeszenie” Wercyngetoryksa jako bohatera narodowego, wykreowanie na takiego w Niemczech Arminiusa/Hermana, a w Anglii króla Artura, nie wspominając już późniejszych poczynań nazistów na tym polu ${ }^{60}$.

Wracając jednak do syntetycznych ujęć nurtów ideologicznych i politycznych przyczyniających się do rozwoju archeologii, i to w skali globalnej, można przywołać propozycję Bruce'a Triggera, który rozmaite tradycje prowadzenia badań archeologicznych na świecie określa jako z jednej strony ,nacjonalistyczne” (przede wszystkim prahistorie poszczególnych państw konstruujące ich narodowe tożsamości, co na przykład w Europie zaczęło następować już od czasów napoleońskich), następnie „kolonialne” (badania rozwijane przez kolonizatorów w regionach, gdzie lokalne społeczności zostały niemal całkowicie zastąpione przez przybyszów, przede wszystkim europejskich, tak jak np. w USA), i wreszcie ,imperialne” (to badania o nastawieniu na skalę światową, prowadzone przez niewielką liczbę państw, takich jak Wielka Brytania, pod władaniem których znajdowały się ogromne obszary na naszym globie) ${ }^{61}$. Do tej klasyfikacji I. Morris dodaje archeologię klasyczną, określając ją jako „kontynentalną”, czyli archeologię

\footnotetext{
${ }^{57}$ Whitley 2001, s. 34-36; Millett 2007, s. 34, 35.

${ }^{58}$ Morris 2004, s. 261.

${ }^{59}$ Pomian 1996a, s. 333; 1996b, s. 145, 146

${ }^{60}$ Arnold 1998, s. 243 n.; Gediga, Piotrowski red. 2004.

${ }^{61}$ Trigger 1984, s. 355-370.
} 
fundującą tożsamość kulturową całej Europy i ukazującą jej starożytne, grecko-rzymskie korzenie, definiującą „europejskość" ${ }^{62}$.

Biorąc pod uwagę dzisiejsze, społeczne funkcjonowanie archeologii, które od lat 90. $\mathrm{XX}$ w. stało się przedmiotem coraz liczniejszych wypowiedzi, a nawet studiów w ramach public archaeology, wypada zauważyć, iż kwestia uwikłania tej dyscypliny w cele ideologiczne, polityczne, propagandowe, a coraz częściej także komercyjne, jest wciąż bardzo aktualna i wymaga krytycznego stosunku badaczy ${ }^{63}$. Nie rozwijając bardziej owego wątku, ale nawiązując do spuścizny klasycznej, ograniczę się jedynie do wspomnienia tak spektakularnego wydarzenia, jakim były igrzyska olimpijskie w 2004 r. w Atenach, które w całości odniesiono do antycznego wzorca. Konsumowanie starożytności, które nastąpiło w Grecji przy okazji owej olimpiady przybrało wręcz wyraz narodowej euforii. Igrzyska, co zrozumiałe, wykorzystano, aby wywołać w świecie zainteresowanie Grecją i skonstruować na jej temat pożądany przekaz, niemniej jednak trudno wskazać bardziej spektakularny przykład odciśnięcia się przeszłości na kulturze współczesnej, i to w pełni akceptowanego. Do tego owa przeszłość w niesłychanie łatwy sposób stała się dobrem konsumpcyjnym dla korporacji finansujących odbywające się przedsięwzięcia. Co więcej, badacze podkreślają, iż stawianie na piedestale w Grecji jedynie wąskiego odcinka jej historii - tego klasycznego, zamiast propagowania rozległej wiedzy o jej przeszłości, wcale nie podbudowuje narodowej dumy, ale wręcz przeciwnie, stwarza trwałą przepaść między ową przeszłością a teraźniejszością ${ }^{64}$. Niektórzy sugerują, w nawiązaniu do szczególnego rodzaju miejsc zdiagnozowanego w eseju M. Foucaulta z lat 60. XX w., iż starożytna Hellada dla współczesnych Greków jest heterotopią, tak przestrzenią geograficzną, jak psychologiczną, jest miejscem pomiędzy wyobraźnią a rzeczywistością, w której klasyczne ruiny stały się emblematem sfetyszyzowanej przeszłości ${ }^{65}$. Dodając do tego trwający już dziesiątki lat spór Greków z władzami British Museum o tzw. marmury Elgina (i nie próbując go w niniejszym tekście nawet streścić oraz przedstawić argumentów obu stron, gdyż przybrał rozmiary publicznej, międzynarodowej debaty, obrosłej obszerną literaturą), zauważyć wypada, iż marmury Partenonu urosły w Grecji do rangi narodowej świętości. Z kolei dla British Museum pozostają oznaką wartości uniwersalnych, a będąc w nim eksponowane mają stać otworem dla zwiedzających z całego świata, co z kolei rodzi krytykę w stosunku do placówki o utrwalanie paternalistycznego modelu muzeum, jako źródła wiedzy promowanej, zamiast miejsca debaty publicznej włączającej możliwie wszystkich ${ }^{66}$.

${ }^{62}$ Morris 1994, s. 11; 2004, s. 259.

${ }^{63}$ Por. na przykład pracę pod redakcją Lynn Meskell z 1998 r. Archaeology under Fire, jak również mój artykuł, w którym szerzej omawiam z kolei kwestię obrazowania przeszłości w rozmaitych mediach plastycznych, problem reprezentacji wizualnych wyników archeologicznych badań nad przeszłością i ich propagandowego oraz komercyjnego wykorzystywania w kulturze współczesnej (B ug aj 2004).

${ }^{64} \mathrm{Hamilakis} 2007$, s. $1-9$.

${ }^{65}$ Leontis 1995, s. 7; P1antzos 2011, s. 613.

${ }^{66}$ Nie tylko British Museum, w związku z debatą na temat rzeźb partenońskich, poddawane jest krytyce, ale również znaczące amerykańskie instytucje muzealne, które wykazują tendencje do organizowania wielkich, 
Pozostając przy uwagach na temat wykorzystywania źródeł oraz badań archeologicznych do celów ideologicznych, pragnę wspomnieć jeszcze jedno wydarzenie ze schyłku ubiegłego wieku, które wywarło istotny wpływ na charakter debat toczonych na gruncie studiów klasycznych, w tym samej archeologii klasycznej. Chodzi mianowicie o ferment i liczne kontrowersje, jakie wzbudziła praca Martina Bernala, Black Athena (1987), w której autor argumentuje, iż „europejskość” cywilizacji greckiej jest produktem wieku XIX i początku XX. Wówczas zamierzano w Europie przywłaszczyć sobie antyk grecki, poprzez swoistą jego konstrukcję, w której pominięto zupełnie pierwiastki afrykańskie i bliskowschodnie, mające go także w znacznej mierze konstytuować. Książka była ogromnym zaskoczeniem dla badaczy pracujących na polu egiptologii, studiów klasycznych oraz historii idei, tym bardziej że autor nie specjalizował się w zakresie języków klasycznych czy bliskowschodnich, a w swej publikacji w znacznej mierze odnosił się do danych filologicznych. Porzucając ponownie wysiłek streszczenia tej dyskusji i przedstawienia argumentów obu stron, co z pewnością także przekracza ramy niniejszego tekstu, a zakładając zaangażowanie Bernala po stronie polityki tożsamościowej i jego afrocentryzm, chciałabym zauważyć, że książka pomimo że bardziej wpisuje się w dyskurs polityczny niż naukowy, na gruncie debat naukowych także zapisała się na trwałe i pominąć już się nie daje ${ }^{67}$.

Powracając do rozwijanego wcześniej wątku historii archeologii klasycznej, zauważyć można, iż po II wojnie światowej studia klasyczne, a w ich ramach rozwijana archeo-

propagandowych wystaw w typie tzw. blockbuster. Dobitnym przykładem takiego przedsięwzięcia była m.in. wystawa zorganizowana w National Gallery of America w Waszyngtonie i Metropolitan Museum of Art w Nowym Jorku w latach 1992-1993, mająca uhonorować 2500 lat demokracji, której początki powiązano z reformami Klejstenesa z lat 508/507 p.n.e. - The Birth of Democracy - An Exhibition Celebrating the 2500th Anniversary of Democracy. Wystawa i towarzyszące jej wydarzenia medialne przerodziły się faktycznie w ociekającą tryumfalizmem manifestację osiągnięć politycznego systemu amerykańskiego, czemu sprzyjał zresztą ówczesny kontekst (przejęcie władzy w 1992 r. w USA przez Demokratów po trzech kadencjach prezydentury Republikanów, a w Europie Środkowej nieco wcześniej upadek systemu komunistycznego wydarzenie o rzeczywiście historycznym znaczeniu). Wystawa jednak była tylko utrwaleniem popularnego rozumienia powiązań pomiędzy zachodnią demokracją a starożytnym systemem politycznym, którego różnorodność i skomplikowanie maksymalnie uproszczono i zmarginalizowano do kwestii ateńskiej demokracji (szersza debata na ten temat oraz w ogóle na temat podejścia do kwestii dziedzictwa kulturowego realizowanego przez wiodące amerykańskie i brytyjskie placówki muzealne, z włączaniem środowiska międzynarodowego, omówiona została w wypowiedzi Deborah Challis z 2008: por. http://www2.open.ac.uk/ClassicalStudies/ GreekPlays/Projectsite/Challis/contents.htm [dostęp czerwiec 2011]).

${ }^{67}$ Publikacji Bernala poświęcony został odrębny panel dyskusyjny na 120 dorocznym spotkaniu American Philological Association w 1989 r., a jako reakcję na książkę, której drugi tom ukazał się w roku 1991, opublikowano dziesiątki wypowiedzi, w tym monografie autorskie i zbiorowe. Część z nich odnosi się do ogólniejszych kwestii multikulturalizmu i przyszłości studiów klasycznych, inne rozważają problem nauczania historii i prowadzenia badań w kontekście współczesnej polityki tożsamościowej itp. Sam Bernal kolejną pracę, tym razem z odpowiedziami na krytykę, publikuje w 2001 r. Zainteresowanych dyskusją odsyłam do obszernego artykułu Tomasa A. Schmitza z 1999 r., w którym autor streszcza poglądy obu stron oraz przedstawia zarówno amerykański, jak i europejski, w tym niemiecki, kontekst tej debaty oraz jej oddziaływanie na grunt studiów klasycznych. 
logia, utraciły swą wyjątkową pozycję, w stosunku do tej, jaką miały wcześniej, przy czym zjawiska te przebiegały odmiennie w Europie i w USA. Proces ów był uwarunkowany licznymi czynnikami, także społecznymi, politycznymi i ekonomicznymi. Niewątpliwie jednym z czynników zasadniczych były zmiany społeczne, które nastąpiły w wielu krajach. Co więcej, odbudowa zniszczeń wojennych, a następnie rozwój inwestycji na licznych obszarach Europy spowodował wzrost liczby wykopalisk lokalnych, szczególnie ratowniczych. Położono też nacisk na rozwój edukacji, i to rozumianej szeroko, często dającej praktyczne umiejętności oraz skierowanej do grona młodzieży, pochodzącej z różnych środowisk. Można uznać, iż w pewnym sensie studia klasyczne uległy demokratyzacji ${ }^{68}$.

Archeologia po II wojnie światowej w Europie Zachodniej zaczęła ponadto umacniać także swą pozycję wśród nauk humanistycznych i społecznych jako nauka prawdziwie „globalna”, pojmowana i promowana jako world archaeology, a niejednokrotnie zainteresowania badawcze wiodących ośrodków, skierowane wcześniej jedynie na starożytności lokalne lub śródziemnomorskie, zwróciły się ku obszarom i cywilizacjom świata, które $z$ kręgiem śródziemnomorskim nie miały wiele lub zgoła nic wspólnego. $\mathrm{Z}$ drugiej strony badania zaczęły obejmować coraz częściej zjawiska niezmiernie odległe w czasie, dotyczące epoki kamienia (także w kręgu śródziemnomorskim), przynosząc nowe, interesujące dla nauki źródła, a to spowodowało, że nie było sposobu, aby archeologia klasyczna utrzymała na polu archeologii jakąś wyjątkową pozycję, co w pewnej mierze wciąż dotyczy historii starożytnej i jej pozycji w ramach historii ogólnej ${ }^{69}$.

Sama archeologia klasyczna przestała z całą pewnością być minionym zabytkoznawstwem, nastawionym głównie na dzieła sztuki, i to często rozpatrywane jako świat autonomiczny, wyłączony z kontekstu swego wytworzenia, funkcjonowania i odbioru. Archeolodzy klasyczni zaczęli odchodzić również od bazowania na danych filologicznych, skupiając uwagę głównie na źródłach materialnych, właściwych dla dyscypliny. Ulegając znaczącym przeobrażeniom, które szczególnie nasiliły się w ostatnich dekadach XX w., archeologia klasyczna zaczęła także istotnie poszerzać zakres swoich zainteresowań oraz weryfikować dotychczasowe podejścia badawcze, a to spowodowało obserwowane już dzisiaj jej zróżnicowanie i zmianę oblicza. Stąd współczesna archeologia klasyczna, widziana jako jedna z wielu równorzędnych gałęzi archeologii, jest dynamicznie zmieniającą się nauką, która przeformułowuje swe pola badawcze i otwiera się na współpracę z wieloma innymi dyscyplinami. Oznacza to, iż podejmuje szeroki wachlarz problemów, m.in. takich jak: studia nad ekologią świata antycznego, nad przestrzenią i krajobrazem, nad procesami urbanizacji oraz procesami państwotwórczymi, nad domostwem i jego zapleczem, badania dotyczące kultu i rytuału, kreacji i ekspresji tożsamości, postrzegania siebie i innego, itd. ${ }^{70}$ Warto przy tym zauważyć, iż archeologia

\footnotetext{
${ }^{68}$ Millett 2007, s. 38, 39.

${ }^{69} \mathrm{Sch}$ aps 2011 , s. 178.

${ }^{70}$ Por. ujęcia powyższej problematyki w przywoływanych już w niniejszym tekście podręcznikach archeologii klasycznej powstałych w kręgu tradycji niemieckiej (Borbein, Hölscher, Zanker red. 2000) oraz
} 
w obrębie nauk o przeszłości pozostaje w jakimś stopniu wciąż dyscypliną unikatową przez to, iż ma poprzez prace terenowe (także coraz liczniejsze nieinwazyjne), jak również wskutek obcowania $\mathrm{z}$ artefaktami, zdolność odkrywania wciąż nowych źródeł i danych w nich zawartych, co obecnie, biorąc pod uwagę możliwość zastosowania w badaniach nowych technologii, otwiera wielce obiecujące perspektywy ${ }^{71}$.

Archeologia, podobnie jak i inne dyscypliny naukowe, stara się przy tym zachować charakter dziedziny suwerennej, o sprecyzowanym polu badawczym. Jest ukierunkowana na konkretne zjawiska przeszłego życia kulturowego i społecznego człowieka, zgłębiane w pierwszej kolejności poprzez dostępne źródła materialne. Otwierając się jednak coraz bardziej na współpracę z różnymi dyscyplinami, również przyrodniczymi, pozbywa się ograniczeń oraz zależności od wybranych humanistycznych dziedzin sterujących, co w przypadku archeologii klasycznej i jej silnych powiązań z filologią klasyczną oraz historią sztuki jest istotne. Nie powinno to oznaczać, jak sądzę, odcinania się i rezygnowania $z$ tej ogromnej i wspaniałej tradycji - wręcz przeciwnie, należy ją przemyśleć i wprząc na nowo w dzisiejsze badania. Autorytet nauki polega na wspólnie opracowanych przez badaczy osiągnięciach, czyli na tradycji, która podlega także stałemu rozwojowi oraz zmianom. Autorytet dobrze rozumianej tradycji nie przeciwstawia się wolności podejmowania nowych badań. W przypadku archeologii, będącej jedną z nauk o przeszłości, należy zdawać sobie sprawę, iż wszelkie pytania o przeszłość zadawane są z pozycji określonej współczesności, są to zatem pytania nie tylko o przeszłość samą, ale i o ludzi współczesnych, myślących o przeszłości z określonej perspektywy kulturowej. Sposób myślenia o przeszłości jest zatem, jak to ujmuje Henryk Mamzer, formą komunikowania przez badaczy ich wyborów wartości i tym samym formą świadomego oraz otwartego na innych uczestniczenia w kulturze, w której są usytuowani ${ }^{72}$. Raz jeszcze powtórzę więc pogląd przytoczony już na początku niniejszego tekstu, iż nasza epoka, podobnie jak poprzednie, kreuje swój własny model starożytności i dokonuje kolejnych interpretacji jej wielorakiego dorobku.

$\mathrm{Na}$ koniec chciałabym przywołać ponownie kwestię ,żywej obecności” antyku w naszej kulturze lub inaczej to ujmując, wyjątkowo mocno zakotwiczony w dziejach Europy pogląd, powtórzony niedawno przez Leszka Mrozewicza, mówiący o antyku jako fundamencie cywilizacji europejskiej: „Jest prawdą obiegową, że cywilizacja Europy wspiera się na trzech wielkich filarach: greckiej myśli i sztuce, osiągnięciach Rzymian w zakresie prawa i organizacji państwa oraz wyrosłym z judaizmu i kultury grecko-rzymskiej chrześcijaństwie, które przyniosło jej w wianie religię i obyczaj" "73. To wciąż powszechne przekonanie dotyczące antyku, które można wesprzeć niezliczoną liczbą przykładów i danych, jest dzisiaj interesujące dla archeologów przede wszystkim

\footnotetext{
anglo-saskiej (Alcock, Osborne red. 2007) oraz liczne odniesienia do konkretnych, publikowanych wyników badań we wspomnianych obszarach.

${ }^{71}$ Millett 2007, s. 46, 47.

${ }^{72}$ Mamzer 2004: por. szczególnie rozdział 3 książki i s. 174 oraz uwagi końcowe, s. 235-239.

${ }^{73}$ Mrozewicz 2008, s. 13.
} 
w związku z refleksją nad rolą antyku w dobie współczesnej oraz potrzebą rozwijania wiedzy o nim. W dalszej bowiem części przywołanej powyżej wypowiedzi L. Mrozewicz stwierdza, że „Inspiracyjna siła antyku, w każdej epoce odczuwana na swój sposób, rozpala umysły pokoleń, które w nim, w jego kulturze i dziejach, szukają motywacji do działania i do przetwarzania otaczającej nas rzeczywistości”, ${ }^{, 74}$.

Wypada mieć nadzieję, że archeologia klasyczna inspirującą również w naszych czasach rolę antyku będzie pokazywać bądź weryfikować takie poglądy, ponieważ funkcjonuje z pełną świadomością, iż teksty, idee, sztuka, jak również kultura materialna starożytnej Grecji i Rzymu, pozostawały dla świata zachodniego bardzo długo kluczowe $\mathrm{w}$ procesie przystosowywania przeszłości $\mathrm{w}$ celu uwierzytelniania teraźniejszości. Współcześni badacze powinni być w pełni świadomi tego procesu, co więcej, podejmując konkretne badania muszą nieustannie „mierzyć się” zarówno z wykorzystywaniem, jak i nadużywaniem tej przeszłości, występującym na zewnątrz ich studiów. Stąd dzisiejsza archeologia klasyczna poszerza znacznie swe pole badań, starając się także określać „,̇ycie społeczne”, role i znaczenia starożytnej kultury materialnej we współczesnym kontekście społeczno-kulturowym. Czyniąc to, bierze pod uwagę rozważania dotyczące koncepcji społecznej sprawczości rzeczy (agency), siłę ich oddziaływania kumulującą się nie tylko w wiedzy na ich temat, zapisywanej zarówno w narracjach archeologów, jak i odkładanej w pamięci społecznej. Uwzględnia również siłę oddziaływania antycznych rzeczy i dzieł na zmysły odbiorcy, z wszystkimi ich właściwościami, takimi jak widzialność i namacalność, co daje im zdolność wciąż na nowo wytwarzania oraz materializowania miejsca i czasu, ucieleśniania przeszłości ${ }^{75}$.

Podsumowując powyższe wywody, oddaję głos poecie, Zbigniewowi Herbertowi, który w jednym ze swych eseistycznych szkiców, dotyczących Akropolu, pisze co następuje:

\footnotetext{
Nie ma na świecie budowli, która tak trwale okupowała moją wyobraźnię. Zdjęcia, rysunki, opisy stanowiły pokarm wodnisty, pozbawiony zapachu, koloru i tła. Znałem nieźle topografię, wymiary i kontur świątyń, ale cały ich zespół położony był nieodmiennie na płaszczyźnie, miał barwę gipsu, nie oddychał światłem, a niebo nad nim było z papieru.

Nie potrafiłem wymyślić żadnego krzewu i przyczepić go do góry, która - tego się obawiałem najbardziej - okaże się nędznym pagórkiem, ani załomu skały, ani nawet cienia, który rzucają kolumny. Wszystko było z rozcieńczonego mleka i tak bardzo linearnie poprawne, że oko i ukryta w oku cząstka dotyku spływały po tym obrazie bez masy i chropowatości, jak po szkle.

Kiedy jechałem tam, rósł we mnie strach, że konfrontacja zniszczy to, co przez wiele lat budowały cierpliwe domysły. I czy będę miał odwagę przyznać się (choćby przed samym sobą), jeśli święte wzgórze i ocalałe na nim resztki świątyń nie przemówią do mnie, jeśli okażą się jedną z wielu, a nie jedyną czy przynajmniej wyjątkową ruiną, pośród wielu rozsianych po świecie ruin? Czy wezmę udział w trwającym od wieków sprzysiężeniu zachwytu, który polega - wiemy to dobrze - nie tyle na wciąż odnawiającym się wzruszeniu, ile na sile wmówienia, na repetycji wiary ${ }^{76}$.
}

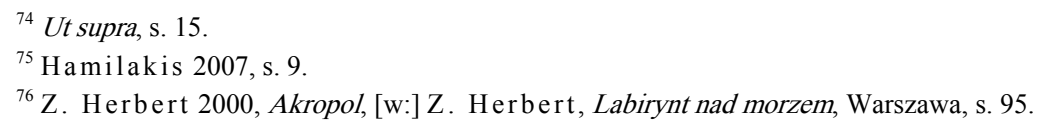


Archeologia klasyczna nie powinna lokować się na pozycjach bezradności wobec kwestii ciągłości cywilizacji, w której tak wiele społeczeństw się rozpoznaje, nie powinna zatem stronić i od debat publicznych na ten temat. Wskazując natomiast na postawioną przeze mnie w temacie niniejszego tekstu kwestię poszukiwania przez archeologię klasyczną - tylko jedną z dyscyplin badającą spuściznę antyczną, swej tożsamości, bardziej ostro rysującą się w ostatnim czasie, niż jest to w przypadku innych gałęzi archeologii, powiedzieć można, iż archeologia klasyczna będzie taką, jaką ją wymyślą badacze, ale wymyślają ją w zależności od tego, jak odczytują i pojmują jej przeszłość i kondycję bieżącą oraz swe miejsce w nauce i społeczeństwie.

BILBIOGRAFIA

Al-Radi S.

2003 The Destruction of the Iraq National Museum, „Museum International” 55, s. 103-107.

Alcock S. E., Osborne R. (red.)

2007 Classical Archaeology, Oxford.

Alpers S.

1991 The Museum as a Way of Seeing, (w:) Exhibiting Cultures. The Poetics and Politics of Museum Display, red. I. Karp, S. D. Lavine, Washington, London, s. 25-32.

Andrzejewski B.

1989 Wilhelm von Humboldt, Warszawa.

Arnold B.

1998 The Power of the Past: Nationalism and Archaeology in 20th Century Germany, „Archaeologia Polona" 35-36 (1997-1998), s. 237-253.

Belting H.

2007 Antropologia obrazu. Szkice do nauki o obrazie, przekł. M. Bryl, Kraków.

Bergmann M.

2000 Repräsentation, (w:) Klassische Archäologie. Eine Einführung, red. A. H. Borbein, T. Hölscher, P. Zanker, Berlin, s. 166-188.

Bernal M.

1987 Black Athena. The Afroasiatic Roots of Classical Civilization, t. 1: The Fabrication of Ancient Greece 1785-1985, New Jersey.

Białostocki J.

1976 U stóp Propylejów. Goethe i plastyka, (w:) J. Białostocki, Pięć wieków myśli o sztuce, Warszawa, s. $116-138$.

Bianchi Bandinelli R.

1988 Archeologia klasyczna jako historia sztuki, przekł. W. Dobrowolski, Warszawa.

Borbein A. H., Hölscher T., Zanker P. (red.)

2000 Klassische Archäologie. Eine Einführung, Berlin.

Bryl M.

2008 Suwerenność dyscypliny. Polemiczna historia historii sztuki od 1970 roku, Poznań.

Bugaj E.

2004 Badania archeologiczne a obrazowanie wizualne przeszłości, (w:) Archeologia - Kultura - Ideologie, red. B. Gediga, W. Piotrowski, Biskupin-Wrocław, s. 253-263. 
Carstens A. M.

2004 Style and Context, „Hephaistos”21/22, s. 7-28.

Challis D.

2008 Exhibiting Democracy. Material Culture from Ancient Athens and the Democratic Ideal, Open University. Reception of the texts and images of antiquity: http:/www2.open.ac.uk/ClassicalStudies/ GreekPlays/Projectsite/Challis/contents.htm

Chippindale Ch., Gill D. W. T.

2000 Material Consequences of Contemporary Classical Collecting, „American Journal of Archaeology” 104, s. 463-511.

Cuno J.

2008 Who Owns Antiquity? Museums and the Battle over our Ancient Heritage, Princeton.

Donohue A. A.

1995 Winckelmann's History of Art and Polyclitus, (w:) Polykleitos, the Doryphoros, and Tradition, red. W. G. Moon, London, s. 327-353.

Dyson S. L.

1993 From New to New Age Archaeology: Archaeological Theory and Classical Archaeology - A 1990s Perspective, „American Journal of Archaeology” 97, s. 195-206.

2006 In Pursuit of Ancient Pasts. A History of Classical Archaeology in the Nineteenth and Twentieth Centuries, New Haven-London.

Gediga B., Piotrowski W. (red.)

2004 Archeologia - Kultura - Ideologie, Biskupin-Wrocław.

Gerhard E.

1850 Archäologische Thesen, (w:) Denkmäler, Forschungen und Berichte als Fortsetzung der Archäologischen Zeitung, red. E. Gerhard, Berlin, s. 203-205 (przedruk oraz przekład na j. angielski por. Gerhard E., 2004, Archaeological Theses, „Modernism / modernity” 11, s. 173-177).

Hamilakis Y.

2003 Iraq, Stewardship and 'the Record'. An Ethical Crisis for Archaeology, „Public Archaeology” 3, s. 104-111.

2007 The Nation and its Ruins. Antiquity, Archaeology, and National Imagination in Greece, Oxford.

Harris J.

2006 Art History. The Key Concepts, London-New York.

Hölscher T.

2000 Bildwerke: Darstellungen, Funktionen, Botschaften, (w:) Klassische Archäologie. Eine Einführung, red. A. H. Borbein, T. Hölscher, P. Zanker, Berlin, s. 147-165.

Lang F.

2002 Klassische Archäologie. Eine Einführung in Methode, Theorie und Praxis, Tübingen-Basel.

Leontis A.

1995 Topographies of Hellenism: Mapping the Homeland, Ithaca.

Mamzer H.

2004 Archeologia i dyskurs. Rozważania metaarcheologiczne, Poznań.

Meier $\mathrm{Ch}$.

2009 Kultur, um der Freiheit willen. Griechische Anfänge - Anfang Europas? Berlin.

Meskell L. (red.)

1998 Archaeology under Fire. Nationalism, Politics and the Heritage in the Eastern Mediterranean and Middle East, London-New York.

Millett M.

2007 What is Classical Archaeology? Roman Archaeology, (w:) Classical Archaeology, red. S. E. Alcock, R. Osborne, Oxford, s. 30-50. 
Morris I.

1994 Archaeologies of Greece, (w:) Classical Greece. Ancient Histories and Modern Archaeologies, red.

I. Morris, Cambridge, s. 8-47.

2004 Classical Archaeology, (w:) A Companion to Archaeology, red. J. Bintliff, Oxford, s. 253-271.

Mrozewicz L.

2008 Antyk fundamentem cywilizacji europejskiej. Wykład inaugurujący rok akademicki 2008/2009,

„Życie Uniwersyteckie” 12 (183), s. 13-15.

Nemo Ph.

2006 Co to jest Zachód?, przekł. P. Kamiński, Warszawa.

Osborne R., Alcock S. E.

2007 Introduction, (w:) Classical Archaeology, red. S. E. Alcock, R. Osborne, Oxford, s. 1-10.

Painter B. W. Jr.

2005 Mussolini's Rome. Rebuilding the Eternal City, New York.

Plantzos D.

2008 Time and the Antique: Linear Causality and the Greek Art Narrative, (w:) A Singular Antiquity. Archaeology and the Hellenic Identity in Twentieth-century Greece, red. D. Damaskos, D. Plantzos, Athens, s. 252-272.

2011 Behold the Raking Geison. The New Acropolis Museum and Its Context-Free Archaeologies, „Antiquity” 85, s. 613-625.

Pomian K.

1996a Zbieracze i osobliwości. Paryż, Wenecja XVI-XVIII wiek, przekł. A. Pieńkos, Warszawa.

1996b Kolekcjonerstwo i filozofia. Narodziny nowożytnego muzeum, (w:) Drogi kultury europejskiej. Trzy studia, K. Pomian, Warszawa, s. 109-172.

2005 Cultural Property, National Treasures, Restitution, „Museum International” 57, s. 71-84.

Potts A.

1982 Wincklemann's Construction of History, „Art History” 5, s. 377-407.

1994 Flesh and the Ideal. Winckelmann and the Origins of Art History, New Haven- London.

Renfrew C.

1980 The Great Tradition versus the Great Divide: Archaeology as Anthropology?, „American Journal of Archaeology" 84, s. 287-298.

Roberts J. (red.)

2005 The Oxford Dictionary of the Classical World, Oxford.

Schaps D. M.

2011 Handbook for Classical Research, London-New York.

Schmitz T. A.

1991 „Ex Africa Lux? Black Athena” and the Debate about Afrocentrism in the US, „Göttinger Forum für Altertumswissenschaft" 2, s. 17-76.

Schnapp A.

1998 La Conquête du passé. Aux origines de l'archéologie, Paris.

2002 Between Antiquarians and Archaeologists - Continuities and Ruptures, „Antiquity” 76, s. 134-140.

2004 Eduard Gerhard: Founder of Classical Archaeology?, „Modernism / modernity” 11, s. 169-171.

$\mathrm{S} \operatorname{cott} \mathrm{S}$.

2006 Art and Archaeologist, ,World Archaeology” 38, s. 628-643.

Shanks M.

1996 Classical Archaeology of Greece. Experiences of the Discipline, London-New York.

Sichtermann H.

1996 Kulturgeschichte der klassischen Archäologie, München. 


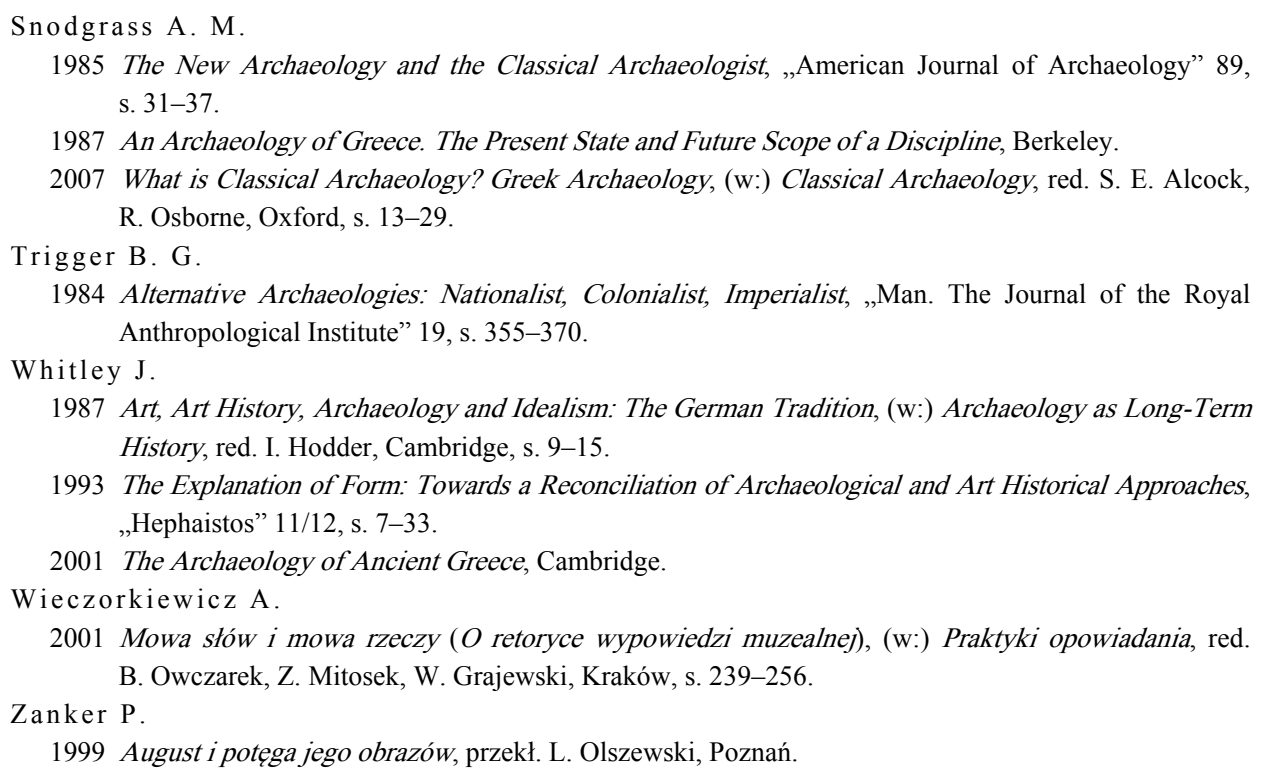

CLASSICAL ARCHAEOLOGY IN PURSUIT OF ITS IDENTITY: BETWEEN THE PAST, THE PRESENT AND THE HISTORY OF ART

\section{Su m m a r y}

The article defines classical archaeology as one of the first and oldest branches of archaeology practised in Europe by stressing that interests in the relics of ancient civilisations have been deeply embedded in the cultural self-identification of various peoples of Europe. A more general issue of a longevity of the „living antiquity” in the history of Europe is also mentioned. Consequently, we used to and remain to speak of the Greco-Roman foundations of the European civilisation, albeit some would argue that such approach to antiquity it no longer feasible.

It is well known that the splendour of Greece has also shined on the ancient Roman world far beyond a simple appropriation of its cultural achievements. Despite difficult Roman-Greek relationships and exploitative attitude of the Romans to the Greek cultural heritage, cultural exchange between these two civilizations was largely of a reciprocal character. Moreover, it is ultimately thanks to mediation of the Romans the Hellenic culture flourished at various areas of their huge empire. One could argue that the first significant synthesis of the complex achievements of ancient culture has already taken place in antiquity. It has then influenced the medieval and Renaissance Europe. Each subsequent period of modern European history has developed its own model of antiquity and re-interpreted and re-defined its sophisticated achievements.

Accordingly, it is justified to claim that the classical legacy is at roots of Europe (hence, classical archaeology is the archaeology of all European countries), regardless the impact of prehistory and the barbarians upon its ultimate character. Therefore, classical archaeology has held an exceptionally privileged position for a long time, as it has not only, similarly to classical studies, aimed to explore 
the ancient past but mainly set to recognize the values developed in ancient world and pass them on to next generations. This no longer the case today when all disciplines are treated equally and pluralistically. Moreover, these values have been drawn from the concept of „Hellenism”, developed already in the eighteenth century and expanded in the following century, which idealised this unique classic Greek past believed to constitute the almost exclusive roots of the „Europeanism”.

However, there are two major factors responsible for the independent development of classical archaeology, in relation to other branches of archaeology, and shaping its specific character. Firstly, this is due to a large number of ancient works of art, in addition to rich iconography, temples and other buildings, which survived to modern times. This legacy - or rather its magnitude and unparallel aesthetic value - resulted in a sole focus on studying the art and architecture and the lack of interest or underscoring other relics of ancient material culture. Secondly, a large number of ancient written sources, in particular numerous inscriptions, set classical archaeology in a privileged position in relation to archaeology of prehistoric societies. Written sources, always regarded as more important than material remains, arguably only ,illustrating” the former, have been almost uncritically considered for a long time as a, ,real” insight into the ancient world.

In the next part of the paper, a very complex relations between classical archaeology and art history is thoroughly discussed by the author.

In conclusion, the author stresses that archaeology, along with other disciplines, attempts to preserve a sovereign character of the discipline with a precisely delimited research field. It is defined in reference to specific phenomena of the past culture and social life primarily recognized through available material remains. However, by opening up on a collaboration with other disciplines, the previously strong attachment of classical archaeology to classical philology and art history has ceased. Nevertheless, this should not mean a wholesale rejection of its great legacy of being a history of ancient art. On the contrary, this traditions ought to be redefined and incorporated into contemporary research agenda of the discipline. The authority of any discipline depends upon its achievements and continuous efforts of scholars. This tradition is a subject of continuous development and change. This authority, however, does not stand in opposition to the freedom of undertaking new research. In case of archaeology, as one of the disciplines studying the past, we must bear in mind that all questions about the past are asked from the position of the present. Therefore, these are not exclusively about the past, but also about contemporary people who think about the past from a particular cultural perspective. Hence, any reference to the past involves communicating the scholars', values and more generally their own embedeness in contemporary culture. Similarly as in previous periods, our own culture creates its own model of antiquity and peculiar interpretation of its numerous achievements.

We should hope that classical archaeology will reveal an inspiring significance of antiquity in our times. Written texts, ideas, representations and material culture of ancient Greece and Rome, have always remained a key resource for the Western world in the process of appropriating the past in order to authenticate the present.

Contemporary classical archaeology has significantly broadened its research agenda by trying to describe the ,social life” and significance of ancient material culture in the contemporary sociocultural context. Accordingly, it takes into account the concept of social agency of things and their impact upon social memory. The other newly introduced issue comprises the influence of ancient artefacts on the recipient senses, including visibility and tangibility of embodying the past, which facilitates an ongoing production and materialisation of time and place. 